\title{
Louis Althusser and Thomas Hardy: How Victorian Ideologies Work in Under the Greenwood Tree
}

\author{
Samira Sasani ${ }^{*}, 1$, Hossein Davari ${ }^{2}$ \\ ${ }^{1}$ Department of Foreign Languages \&Linguistics \\ Shiraz University \\ ${ }^{2}$ M.A. Student of English Literature, Shiraz University \\ E-mail address: samira.sasani21@yahoo.com
}

Keywords: Victorian ideology; Louis Althusser; Under the Greenwood Tree; oppressive ideologies

\begin{abstract}
In his early novel, Under the Greenwood Tree, Thomas Hardy attempts to show the readers how the inhabitants of a small village are repressed by the ideologies the dominant class or capitalism defines for them. The aim of these suppressive programs is to oppress the individuals by making them good and subordinate subjects. Althusser calls these ideologies created by the dominant class, Ideological State Apparatuses; however, in this novel one observes how some of the subjects try to revolt against these cruel rules by defining their own ideologies. One can also recognize that how the blatant break of these ideological programs by the revolutionary subject makes the subject look weird and eventually how he/she is alienated and marginalized by the society. On the other hand, the good subjects are made to believe that following these ideologies is usual and breaking of them is synonymous with interfering with the discipline and order of nature. Brought up in the Victorian age, Hardy understands how people are controlled by the ideologies and how they subscribe to them unwisely. In this novel he shows how a new and up-date product of capitalism - the organ - is introduced to a very traditional atmosphere in order to indoctrinate new changes in it. The so-called good subjects simply believe that change is necessary and inevitable. But this change has wisely planned by the oppressive capitalist powers for whom this change means the manipulation of these docile subjects, not only by separating them from their music community but also by depriving them of their traditional music.
\end{abstract}

\section{INTRODUCTION}

Marxist critics believe that text is the product of its society and reflects it. No text then can avoid showing the context in which it is written. But what is a society? What are the rules that control that society? Who controls these rules? To what aim(s) are these rules defined? Briefly speaking, society is a body of rules or programs, defined by the dominant class and those in power, to which people of that society must subscribe; however, these oppressive rules are not recognized by many people, who are called good subjects by these capitalists, since these rules are internalized in them.

But what is an ideology and how does it operate? In his influential essay, "Ideology and Ideological State Apparatuses", Althusser describes ideology. Traditionally ideology was considered as a kind of "'false consciousness' as a set of practices and institutions that sustain an individual's imaginary relationship to his or her material conditions of existence" (Rivkin and Ryan 693). Althusser sees ideology "as a 'social practice which helps conceal the true nature of social reality-economic and political" (qtd.in Makaryt 599). These programs are imposed on people by the superstructures of the society, the institutions such as church, government, state, social service and educational system, which are authorized by people in power such as kings and priests. Althusser describes the oppressive powers as such:

'forged' the Beautiful Lies so that, in the belief that they were obeying God, men would in fact obey the Priests and Despots . . . There is therefore a cause for the imaginary transposition of the real conditions of existence: that cause is the existence of a 
small number of cynical men who base their domination and exploitation of the 'people' on a falsified representation of the world which they have imagined in order to enslave other minds by dominating their imagination.(qtd.in Rivkin and Ryan 694)

These ideologies are making a false consciousness and an allusion of reality for the subjects and therefore are making them good and non-revolutionary persons as Althusser declares: "social meanings are both arbitrary and self-referring, social realities mere simulacra, and [all of us are] ... prisoners of language" (qtd. in Payne 31). Thus, capitalist ideologies such as classism and consumerism have one role: to help those in power maintain perpetually in power.

Another medium helping capitalism maintain in power and reinforces its oppressive ideologies is commodification. "Commodification is the act of relating to the objects or the persons in terms of their exchange value or their sign-exchange value" (Tyson 62). For example, if a person commodifies another one, the abused person confers its money or social status on the oppressor.

\section{DISCUSSION}

Thomas Hardy's Under the Greenwood Tree Shows how the low and middle-class characters are oppressed by the oppressive ideologies of the capitalism and aristocracy; besides, it shows how they are deceived by the false consciousness which is provided for them by those in power, also it shows how they subscribe to the capitalist ideologies and how they are commodified and alienated by those conducting these programs.

The Victorian period (about 1832 to 1902) is divided into two phases; the early and the late Victorian period. The first began in 1832 and closed in 1868 and the second extended from 1868 to 1902. "The late Victorian period includes three decades of commercial and industrial rivalries, imperial expansion, and increasing political, social, economic, and spiritual anxieties."(Abjadian 308). Written in 1872, Under the Greenwood Tree belongs to the second realm, a period replete with economic and industrial expansions. The work shows how people are controlled by the ideologies which are the result of this economical and industrial atmosphere. These repressive ideologies such as consumerism, women's meager social standing, forged religion, strict marriage law and classism reinforce the dominant economic condition which is controlled by capitalism.

The role of women in Victorian era was different from that of men. Women were considered inferior compared to men. For this reason they were not allowed to attend universities and social activities. Men were the productive agents in the society. Though it was really the women who gave birth to and reared these men, women's role in the society was unfairly ignored. These women forgot their own interests, passions, and desires, while they were satisfying the needs of others. "For women, however, work meant labor for others. Work, in the sense of self-development, was in direct conflict with the subordination and repression inherent in the feminine ideal" (Showalter 22). Being bereft of their rights, the self-negating Victorian women were suppressed by this ideology allocating them in lower position than men's position in the society. The Victorian woman was perfectly a good subject meeting three conditions: First, negating her personal desires; second, restricting herself to home; third, choosing an inevitable religiously pure life. It is the repressive ideology the society has internalized in her and she considers it as something normal and natural. Showalter mentions:

The middle-class ideology of the proper sphere of womanhood, which developed in post- industrial England and America, prescribed a woman who would be a perfect lady, an Angel in the House, contentedly submissive to men, but strong in her inner purity and religiosity, queen in her own realm of the Home. (14)

In this novel one observes that women do all the domestic works in the home; additionally, they do not participate in the social activities which is discussed and operated by men. For instance, Mrs. Dewy and Day easily accept this ideology by restricting themselves to home and not making any objection against it. Indeed they are a prototype of good and obedient Victorian woman; further, they are good subjects of the society denying their rights. On the other hand, Fancy Day is the opposite of these obedient women. She is an educated teacher who is not restricted to home and domestic activities. She is therefore the transgressor of this repressive ideology controlling the 
women of the society. Her role, as the player of the organ, shows her interest in participating in social activities which are monopolized by men. Another violator of these ideologies is Elizabeth Endorfield, who not only blatantly violates the dominant ideology in the society but also flagrantly violates all other rules. For this reason, she is regarded as an evil and imperfect woman who is insane:

She was shrewd and penetrating; her house stood in a lonely place; she never went to church; she wore a red cloak; she always retained her bonnet indoors; and she had a pointed chin. Thus far her attributes were distinctly Satanic; and those who looked no further called her, in plain terms, a witch. (Hardy 166; Ch.4)

From Marxist point of view, religion is another repressive ideology controlling people's lives. People accept it as a program sent by God; the God who works only for the benefit of His people. Unfortunately, religion is misused in the hands of the oppressive powers. While misused by those in power, the forged religion is employed to reinforce the dominance of those in power and to make the people of middle and lower middle class consent to their meager position, and thus make them submissive; thus they do not revolt against the oppression which is imposed on them. Michael Millgate says, Hardy "was never to lose entirely his imaginative adherence to the church, his love of its music and its services, and its belief in its civilizing and socializing function"(qtd.in George Levine 44). It can be inferred that even those who have lost their faith in Christianity like Hardy are permanently attached to church which has a civilizing and socializing function. In this novel, people are controlled by the church; the authorities of the church, Mr. Shinar and the Vicar are two crafty men who deceive these naive people; moreover, they are the representatives of the oppressive ruling class. By using the authority of the church, they portray a false consciousness for the naïve people of the Mellstock in order to satisfy the needs of capitalism. The ruling class does not care about their music; the only thing it requires is the attendance of the dwellers to the church. They make people accept the forged religion, which is a repressive ideology; while people are not aware of it.

It is easily recognizable that the vicar and Mr. Shiner commodify these people to fulfill the needs and the desires of the ruling class. They make a false consciousness in them by making them believe that the music which is their own product will be always their own and will benefit them socially but actually this is the ruling class which benefits from it. These people are also made to believe that they must respect Mr. Shiner and the vicar; the former is wealthy and powerful and the latter is a man of God who is therefore superior to all the inhabitants. The Mellstock dwellers consider them, financially and socially, superior so they must be esteemed. This ideology of classicism along with the false consciousness it creates control the people, so the naïve men and women do not protest against it. Even Dick's hatred of these characters which is shown in the form of silence is not because of his awareness of their oppression but on the other hand, he hates them because they are his love rivals desiring Fancy.

This is interesting to note that even Fancy whose individualistic characteristics made her a partly non-obedient subject is not completely spared from this false consciousness. She is the player of the instrument and though she thinks she is playing on her individuality, though, she is unknowingly manipulated by Mr. Shiner who has selected her not because of his love for her but because she is an educated and well-versed woman whose attendance at the church not only brings prestige for the church but also dissociates the obsolete music community, and introduces the new and up to date product of capitalism, the organ. "Although Mr. Shiner has apparently singled her out as the organist because of his love of her, his real intention is the selection of one with higher education, behavior and rank". (Keshavarzi and Abjadian 109)

When love between Dick and Fancy is established, the only obstacle is her father's permission; accordingly, it is obvious that the father's permission is necessary for the marriage of a Victorian girl. Father's permission is a part of the strict marriage law preventing the true lovers from being united. When Dick is confronted with Mr. Day, Fancy's father, though he loves Fancy, he withdraws from the marriage since Mr. Day convinces him that he is socially inferior to her daughter and that she deserves a grand union with a rich man who is socially equal to his daughter. 
Dick's response to Geoffrey Day is a strong evidence of his familiarity with the dominant discourses; that is, the ideology of hierarchy. Dick as a subject of his society understands that he is naturally lower than Geoffrey, the subject, and he should not expect any other treatment than what he has encountered when courting Fancy. (Keshavarzi and Abjadian 113)

Mr. Day admonishes Dick for his unwise treatment since he should have considered his inferiority compared to the status of Mr. Day's daughter. That's why Dick wishes to be rich like Mr. Shiner. So, it is wealth and social standing that define the worth of the individuals. It is interesting that Fancy revolts against that repressive ideology by forcing her father to consent to their marriage. Through starvation, she objects to her father's unfair decision; accordingly, Geoffrey Day who sees her daughter in that condition has no other alternative but permitting her to marry Dick.

In this novel the relationship between the couples is not passionate and enthusiastic. One does not really feel the existence of a romantic love between the couples. That is because it is taboo for them to show their desires specially those sexual ones which are in contrast with their strict moralism. James Eli Adams declares: "almost from its first wide currency in the late nineteenth century, 'Victorian' has been a byword for a righteous moralism centered on sexual repression" (qtd. in Mathieson 2).

The role of woman in the family was mostly defined with regard to her duty towards her husband and children and her relationship with them is not out of love for them. In other words, Marriage was a social fact for them not an affectionate commitment. "The Victorian society held rigid 'views on marriage' and the role of women in life. Most women regarded marriage as a fixed fact of nature. It was a fundamental part of their life plan, as was childbearing (Chattopadhyay 24). Again Fancy, who is different from the Victorian women among whom she lives, chooses Dick because she loves him as Dick does. Unlike other Victorians, the mutual love between them is the only reason for their marriage. Fancy could have chosen Mr. Shiner who was socially higher and richer than Dick; besides, she could have also selected the Vicar who had a powerful and high social standing among the others; nevertheless, she picked Dick out of love. Their marriage is therefore a revolt against the calculated and unaffectionate marriage of the Victorian age.

Another repressive ideology which can be detected is consumerism. It is a repressive ideology because it makes a false consciousness in the costumers. In other words, the worth of the individuals is evaluated by the products they buy. If they buy expensive products, they are worthy and if they buy inexpensive things they are unworthy. In this novel, the Day family is oppressed by this ideology. When Dick steps in the house, he finds the house full of the capitalist products such as: furniture, two clocks, cups, plates, two Bibles, two warming-pans, and two intermixed set of chairs. These products distinguish the Day's house from other houses in that village. The family shows the ideology of the capitalism and reinforces its dominance by supporting it financially. Moreover they make a false consciousness in the customers that they are worthy because they have bought products which other people do not afford to buy; the products which are bought merely for the sake of sign-exchange value. As an instance, the existence of two Bibles in Mr. Day's house is symbolic and does not have any use-value. It is symbolically used to show the visitors that the Day family is a religious and thus a respectable family. The house is too full for a family of three; it is too full to show people that the Day family affords to buy, so they are upscale and first class.

Companies compete with one another to sell their products which belong to the ruling class; selling of these products makes the capitalists more affluent. The existence of two clocks which belong to two well-known makers is therefore important. They symbolically show the rivalry of the companies trying to sell their products. The customer is thus the oppressed agent who has bought both clocks for the sake of a void value: the sign- exchange value. Hardy depicts this condition as such: "They were two departed clockmakers of Casterbridge, whose desperate rivalry throughout their lives was nowhere more emphatically perpetuated than here at Geoffrey's" (Hardy 97; Ch.2).

As the repressive ideologies are discussed, it can be claimed that all the characters of this novel except Elizabeth Endorfiled are repressed by these ideologies. Even fancy who has some revolutionary thoughts is not spared from being oppressed by some of these ideologies. Though 
Fancy has violated against some of the repressive ideologies of Victorian era such as strict and harsh rules of Marriage and women's meager and oppressed social standing, she is still oppressed by the repressive consumerism. She always changes her dresses in different situations to demonstrate that she can buy what other people cannot and is therefore superior to them. These distinguished dresses are the products of capitalism and manifest sign-exchange value. In addition, she is controlled and commodified by the workers of Capitalism, Mr. Shiner and the Vicar. As mentioned before, they use her to introduce the new product of capitalism - the organ.

Elizabeth is different from all the suppressed characters. Because she is not repressed by any of the existing ideologies, she does not care about marriage laws, forged religion, consumerism, and all other repressive ideologies of Victorian era. Thus she is treated as an abnormal woman who is entitled a witch by the good subjects and the oppressive agents in power. She shows how the society treats a person who does not succumb to its rules. Consequently, she has no other choice but staying outside the scope of the society. Since she knows that the church is an institution of the forged religion of the dominant class whose aim is to control the individuals and to reinforce their subjectivity, she does not go to the church. In comparison to the obedient and docile subjects who are deceived by the ideologies which have been internalized in them, Elizabeth is a bad subject due to the fact that she has recognized these rules as oppressive ideologies and nothing natural at all. She is very different from all the docile men and women; thus, such differences make her unfavorable by other people, especially the dominant oppressive powers. The only character who is affected by her is Fancy, since besides her obedient side she has a revolutionary side which is inflamed by Elizabeth's awareness. Had not she met Elizabeth, she would not have found the way how to revolt against her father's unjust decision about her affair with Dick.

Considering these repressive ideologies, one may ask how and why women's social standing and marriage laws are considered as the repressive ideologies of the dominant class. As mentioned before, the aim of these ideologies is to create good and obedient subjects. By depriving the women of their rights and restricting them to the domestic realm, capitalism aims to strengthen the women's subjectivity. Thus the woman has one hope, to marry a person who is socially and financially higher than her. In other words, women's meager social standing and strict marriage laws finally result in the acceptance and reinforcement of classism. One may also ask how ideologies are transmitted to the readers? Is Thomas Hardy against or for these ideologies? One of the best media in order to transfer ideologies is literature, especially a literature including comic elements.

Thomas Hardy's novel represents a humorous and entertaining depiction of the musicians. In this novel the readers are entertained by the dwellers' words and conducts and they forget about the unfair situation in which these people live. For instance, the seventy-year-old William who is the oldest person in the novel, who is to be portrayed as a venerable and respected elder is depicted humorously. He is treated as a good hearted child, weak minded Dewy, and old William. The way they choose to address William depends on their mood:

If they saw him pass by their windows when they had been bottling off old mead . . . they thought concerning him, Ah, there's that good-hearted man-open as a child! If they saw him just after losing a shilling or half-a-crown . . . they thought, there is that poor weak-minded man Dewy again! Ah, he's never done much in the world either! If he passed when fortune neither smiled nor frowned on them, they merely thought him old William Dewy. (Hardy 15; Ch.1)

The pastoral atmosphere of Hardy's novel deviates the minds of the readers from the people's condition in which they are entrapped. Actually, it makes the readers forget the unhappy condition of the oppressed people; very much like the readers the docile and so called good subjects' minds diverge from these unfair ideologies. Instead of revolting against the repressive ideologies controlling them, they are entertained with feasts. 
It seems as if Thomas Hardy is consciously the supporter of these ideologies. He creates an idyllic and felicitous situation where people live happily. This pastoral atmosphere is actually a veneer under which the offensive reality is concealed. In this novel, the people are confronted with a new product which threatens their community but finally the instrument replaces their traditional music. The novel ends happily with a marriage though the future problems of the musicians are remained open and undecided. Hardy's hero is docile and oppressed by the ideologies, he also does nothing to break these suppressive rules; additionally, his heroine, though has some revolutionary ideas, is inherently a docile and good subject who like all the musician is manipulated by the two villains. The only subversive character is Elizabeth Endorfilled who, because of her revolutionary thoughts, is called a witch and is not acclaimed by the characters whose words and conducts are given to them by Hardy. It seems as if Thomas Hardy entertains us by an entertaining novel which ends happily in order to make us forget the oppressive situation in which his characters live.

\section{CONCLUSION}

Under the Greenwood Tree is a novel in which many Victorian ideologies control the lives of its subjects who unknowingly accept these oppressive programs as natural rules. Being internalized in them, these ideologies ensure the ultimate goal of capitalism which is the permanent dominance in the society. Presenting an idyllic and pastoral atmosphere, which tries to recapture those calm days before the Victorian period, Hardy deviates the minds of readers from the real catastrophic situation in which these naïve subjects live. The only person with revolutionary thoughts though not enough to make her a fully subversive character, like Elizabeth Endorfield, is Fancy Day whose social standing and individualistic decisions make her different from all the women in the novel who are perfect prototypes of a Victorian woman. The only fully depicted revolutionary character who knows the inherent goals of these oppressive ideologies is Elizabeth Endorfield whose knowledge, awareness and revolt are the cause of her alienation. Thomas Hardy explicitly shows that the ideologies must be obeyed by the subjects and if a person does not obey the rules of the society, he is marginalized and is not accepted by the dominant oppressive powers, since it would be a stimulus for the docile and so-called good subjects of the society and thus a dangerous and threatening agent for the oppressive and domineering powers.

\section{References}

[1] Abjadian, A. A Survey of English Literature(II). 6th ed. Tehran: SAMT, 2010. Print.

[2] Althusser, L. Ideology and Ideological State Apparatuses. In Literary Theory: An Anthology. 2nd ed. Julie Rivkin and Michael Ryan (Eds). London: Blackwell, 2004. 693-702. Pdf.

[3] Chattopadhyay, A. Women in Victorian Society as Depicted in Thomas Hardy's Novels. International Journal of Educational Planning and Administration. 1 (1) (2011) 23-28. Pdf.

[4] Hardy, T. Under the Greenwood Tree or the Mellstock Quire: A Rural Painting of the Dutch School. London: Macillan and Co LTD (1995). Print.

[5] "Ideology". In Encyclopedia of Contemporary Literary Theory: Approaches, Scholars, Terms. Irena R. Makaryk (Ed.). 5th ed, Toronto: University of Toronto Press (2000). Print.

[6] Keshavarzi, A, and A. Abjadian. Thomas Hardy's Under the Greenwood Tree: An Althusserian Perspective. The Journal of Teaching Language Skills. 3 (1) (2011) 99-118. Print.

[7] Levine, G. Hardy and Darwin: An Enchanting Hardy? In A Companion to Thomas Hardy. 1st ed. Keith Wilson (Ed.). London: Wiley-Blackwell (2009) 36-53. Print.

[8] Mathieson, Ch. Introduction: Sex, Courtship and Marriage in Victorian Literature and Culture. Victorian Network. 4 (2) (2012) 1-9. Pdf. 
[9] Payne, M. Reading Knowledge: An Introduction to Barthes, Foucault and Althusser. 1st ed. London: Blackwell (1997). Print.

[10] Showalter, E. A Literature of their Own: British Women Novelists from Bronte to Lessing. New Jersey: Princeton University Press (1997). Print.

[11] Tyson, L. Critical Theory Today: A User-Friendly Guide. 2nd ed. New York: Routledge (2006). Print. 